\title{
Lectin-Like Binding of Four Animal Lactobacilli Considered for their Use in Probiotical Preparations
}

\author{
I. Štyriak ${ }^{*}$ and I. Štyriaková
}

\author{
Institute of Geotechnics, Slovak Academy of Sciences, Košice, Slovakia
}

\begin{abstract}
Four gut lactobacilli (Lactobacillus plantarum L5, Lactobacillus paracasei L81, Lactobacillus fermentum L 670 and Lactobacillus casei subsp. pseudoplantarum L.c.) were examined by particle agglutination assay (PAA) for their lectin-like binding activity after their cultivation on Rogosa agar and in MRS broth. Seven ECM (extracellular matrix) molecules (bovine mucin, porcine mucin, bovine fibronectin, porcine fibronectin, fetuin, bovine lactoferrin and heparin) were selected for this assay. Moreover, haemagglutination tests with pig, cattle, sheep, and hen erythrocytes were performed. However, none of the four Lactobacillus strains examined did react with any of the erythrocytes tested. The differences between individual strains were observed in their binding to immobilised ECM molecules. The best adherent were the Lactobacillus plantarum L5 and Lactobacillus paracasei L81, however, the other two strains showed also good ECM binding of some ECM proteins. With regard to an influence of cultivation medium on lectin-like binding activity, binding of all ECM molecules was expressed in Lactobacillus paracasei L81 to significantly higher degree after cultivation on Rogosa agar than in MRS broth. Similarly, strains Lactobacillus fermentum L670 and Lactobacillus casei subsp. pseudoplantarum L.c. displayed significantly higher binding of fibronectin and mucin after growth on Rogosa agar in comparison with MRS broth cultivation. The influence of cultivation medium on fetuin binding by Lactobacillus fermentum L670 was also not significant while Lactobacillus casei subsp. pseudoplantarum L.c. bound fetuin significantly better after growth on Rogosa agar.

Heparin pretreatment increased the binding of the ECM molecules by the Lactobacillus fermentum L 670 strain significantly with the exception of porcine fibronectin when the strain was cultivated in MRS broth. Similar positive effect of heparin was observed also in the other three lactobacilli. This result is important especially in the connection with the observations that heparin decreased ECM binding of enteropathogens as staphylococci or clinical enterococcal isolates. Following up on some earlier strain characteristics, these results confirm that the selected lactobacilli are suitable for probiotic purposes.
\end{abstract}

Keywords: Lactobacillus, ECM proteins, extracellular matrix, collagen, fibronectin, albumin, vitronectin, lactoferrin, fetuin, mucin, probiotic use.

\section{INTRODUCTION}

Both indigenous and pathogenic bacteria are able to attach to host cells, and attachment is assumed to be a critical parameter for colonization of mucosal surfaces by microorganisms [1, 2].

Lactobacilli are members of the normal mucosal microflora of most animals. Hundreds of papers report the use of various Lactobacillus strains as probiotic agents for human and animals. Moreover, several requirements have been identified as important properties for lactobacilli to be effective probiotic organisms [3, 4]. Their effects are considered to include the prevention of gastrointestinal infections [5, 6], enhance immune response [7, 8], and antimutagenic as well as anticarcinogenic activity $[9,10]$.

When selecting strains for probiotics, it is necessary to respect the origin of the strain used, its ability to survive and grow in the respective ecological unit [11].

*Address correspondence to this author at the Institute of Geotechnics, Slovak Academy of Sciences, Košice, Slovakia; E-mail: styriak@saske.sk

ISSN: 2223-3806 / E-ISSN: 1927-5951/16
Recently, the idea has emerged to select among lactic acid bacterial strains those which are able to be incorporated into the resident flora and to demonstrate beneficial potentialities, then to investigate their biological effects both in vitro and in vivo, and finally use them in probiotical products offering health benefits $[12,13]$.

The extracellular matrix (ECM) is a mixture of secreted proteins composed primarily of collagens, fibronectin, laminin, and proteoglycans located on epithelial and endothelial cell surfaces [14]. Adherence of pathogens to ECM of various host tissues has been often investigated, demonstrating the important role of these interactions in the establishment of many infections $[2,15]$. However, very little is known about members of the indigenous microflora, including lactobacilli, and their ability to bind ECM proteins despite some studies demonstrating collagen [16-20] and fibronectin binding $[14,20]$.

Lactobacillus populations are very interesting within the gastrointestinal tract of piglets, due to their purported benefits for gut function and health [21]. While, these Lactobacillus populations establish early 
in the piglet, succession occurs throughout the pig's lifetime, with lactobacilli remaining a predominant portion of the population [22]. The strains for our study selected show a series of features which make them particularly promising for the preparation of probiotic products. The characteristic features of the strains used are strong adherence to epithelial gut cells as well as inhibitory activity against enteropathogenic E.coli under in vitro conditions [5]. These lactobacilli were also confirmed as producers of organic acids that generated an inhibitory barrier against digestive tract pathogens on the mucosa of the small intestine [23]. Hydrogen peroxide, an inhibitory substance to pathogens may be one of the responsible factors in the dominance of lactobacilli [24] except organic acids and bacteriocins. Lactobacillus plantarum $\mathrm{L} 5$ and Lactobacillus casei subsp. casei $\mathrm{L} 81$ produce hydrogen peroxide in detectable amounts [25]. The adherence of lactobacilli to gut cells in vitro correlated with their ability to adhere to the mucosa of both jejunum and ileum in gnotobiotic piglets [5]. Gnotobiotic piglets were used in some previous experiments because they provide epithelial surfaces in a defined, living system in which a single attribute of an organism (i.e. the ability to colonize an epithelium) can be tested. However, this model is not suitable for experiments directed to the investigation of lectin-like binding ability of bacteria.

The study of haemagglutination properties has been considered as a convenient and effective way to investigate the presence of adhesins on bacteria [26, 27]. Moreover, Adlerberth et al. (1996) [28] demonstrated that the carbohydrate-binding ability leading to haemagglutination of Lactobacillus plantarum is closely related to the ability to adhere to intestinal epithelial cells. That is why we decided to examine a haemagglutination activity of four lactobacilli which were investigated also for their ECM-binding properties and are considered for their use in probiotical preparations.

\section{MATERIALS AND METHODS}

\section{Sources and Cultivation of Strains}

Three Lactobacillus spp strains (Lactobacillus plantarum L 5, Lactobacillus paracasei L 81 and Lactobacillus fermentum $L$ 670) originally isolated from the jejunum and ileum of piglets as well as Lactobacillus casei L.c. from the intestinum of a calf were used in this study. They were obtained from Dr. Radomíra Nemcová from Veterinary University in Košice (Slovakia). Two growth media were examined for their influence on the expression of the surface receptors of all strains tested. Lactobacilli were grown overnight in Man-Rogosa-Sharpe (MRS) broth (Difco Laboratories, Detroit, MI, USA) and on Rogosa agar plates (Difco) at $37^{\circ} \mathrm{C}$ in $5 \% \quad \mathrm{CO}_{2}$ atmosphere. Staphylococcus haemolyticus SM 131 as well as E. coli strains On-6, AX 139, AX 35 and AX 16 from the Collection of Microorganisms of the Medical Faculty of the UPJŠ (Pavol Jozef Šafárik University) Košice (Slovakia) were used as positive controls in haemagglutination tests.

\section{Chemicals}

ECM molecules (bovine mucin (BM), porcine mucin (PM), bovine fibronectin (BFIB), fetuin (FET), bovine lactoferrin (BLACT) and heparin (HEP), porcine plasma fibronectin (PFIB) from Biolnvent International $A B$ (Lund, Sweden). All buffers and chemicals were of analytical grade.

\section{Adsorption of ECM Proteins to Latex Beads}

Proteins were adsorbed to the Difco latex beads by electrostatic and hydrophobic interactions as described previously $[19,29]$.

\section{Particle Agglutination Assay (PAA)}

The protein-coated latex beads $(15 \mu l)$ were mixed on a glass slide with an equal volume of a bacterial cell

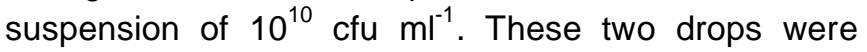
gently mixed and the agglutination reaction was scored after 2 min as a PAA value from strongly positive (3) to weakly positive (1) or negative (0) as previously described by Štyriak et al. (1999b) [30].

\section{Erythrocytes and Haemagglutination Tests}

After being collected, pig, cattle, sheep, and hen erythrocytes were washed three times with phosphatebuffered saline (PBS), $\mathrm{pH}$ 7.0. Bacterial cells grown on Rogosa agar plates (Difco) at $37^{\circ} \mathrm{C}$ in $5 \% \quad \mathrm{CO}_{2}$ atmosphere were harvested and washed once with PBS and resuspended in the same buffer to a final concentration of $10^{9} \mathrm{cfu}$ per $\mathrm{ml}$. Moreover, bacteria grown in MRS broth were centrifuged and washed once with PBS and resuspended in the same buffer to a final concentration of $10^{9}$ cfu per $\mathrm{ml}$. Haemagglutination (HA) tests were carried out as described previously by Mukai et al. (1998) [27] at either $4^{\circ} \mathrm{C}$ or $37^{\circ} \mathrm{C}$ in 96 -well U-bottom microtitre plates. Staphylococcus haemolyticus SM 131 as well as E. coli strains On-6, AX 139, AX 35 and AX 16 were used as positive controls in haemagglutination tests. 
Table 1: Binding (PAA Score) of Four Animal Lactobacilli to ECM as Tested by Particle Agglutination Assay

\begin{tabular}{|c|c|c|c|c|c|c|c|}
\hline Strain & BM & PM & BFIB & PFIB & FET & BLACT & HEP \\
\hline Lactobacillus plantarum L 5 & 0 & 1 & 3 & 0 & 1 & 0 & 3 \\
\hline Lactobacillus paracasei L 81 & 0 & 1 & 3 & 0 & 1 & 0 & 3 \\
\hline Lactobacillus fermentum L 670 & 0 & 1 & 2 & 0 & 0 & 0 & 2 \\
\hline Lactobacillus casei L.c. & 0 & 0 & 1 & 0 & 1 & 0 & 2 \\
\hline
\end{tabular}

\section{RESULTS}

The PAA score (Table 1) displays some differences among lectin-like binding ability of 4 selected strains tested by PAA.

With regard to an influence of cultivation medium on ECM binding, Rogosa agar permits in most cases a better expression of bacterial surface structures than MRS broth because a higher bacterial binding was observed after cultivation of the strains on Rogosa agar plates than in MRS broth. However, in some cases no significant or opposite effect of medium was observed.

Concerning the study of haemagglutination properties, none of the four Lactobacillus strains examined did react with any of the erythrocytes tested.

\section{DISCUSSION}

It is more and more recognized that the resident microflora of the gastrointestinal tract plays an important role in inhibiting gut colonization by incoming pathogens [31, 32]. Probiotic agents, live microorganisms with beneficial effects for the host, may offer an alternative to conventional antimicrobials in the treatment and prevention of enteric infections. This alternative is very actual especially nowadays when increasing antibiotic resistance may soon render conventional therapy inadequate for many infections. While the expression of the factors listed in some review articles (e.g. Reid, 1999) [4] is likely important for probiotical activity, it is not easy to grade the extent to which any given property is essential or of greatest importance in vivo. However, it seems that adherence and expression of some antagonistic activity against pathogens, especially against their adhesion, belongs to the most critical factors, but that fact does not exclude other properties [4].

Neeser et al. (2000) [32] corroborated by their findings the hypothesis that selected probiotic bacterial strains could be able to compete with enteropathogens for the same carbohydrate receptors in the gut. Mack et al. (1999) [33] proposed on the basis of their in vitro studies the hypothesis that the ability of probiotic agents to inhibit adherence of attaching and effacing organisms to intestinal epithelial cells is mediated through their ability to increase expression of MUC2 and MUC3 intestinal mucins. The capacity to adhere to components of the mucosa and thus avoid rapid exclusion from a beneficial environment must be a high-priority task for an intestinal organism [34]. These findings put a new light on the way by which probiotic bacteria can provide protection to the gut against microbial pathogens.

Four gut lactobacilli, investigated in this study by PAA for lectin-like binding activity, were previously examined for their collagen binding [19] and now we extended our study by screening of these strains for lectin-like binding abilities. As shown in Table 1, many significant differences between individual strains were observed in the binding of these immobilised proteins. The ECM structures may be expressed on the surfaces of eucaryotic cells such as epithelial, endothelial, fibroblasts, erythrocytes, etc.

Mucin from porcine stomach was used as a model to confirm a mucin-binding activity of lactobacilli because it is known that mucin molecules serve as initial binding sites for most of enteric and other bacteria [35]. Since cell surface lectins could be involved in recognition events associated with many bacterial diseases, fetuin called also "lectin screening protein" was also used in our study.

Several glycosaminoglycans form part of the extracellular matrix and that is why heparin, a representative of this group, was chosen as a model to study glycosaminoglycan-binding ability. Heparin is distributed widely in the human body [1], stored intracellularly in mast cell granules and released on mast cell degranulation in an allergic response [36].

In order to compare ECM binding of the strains after their cultivation on solid and in liquid medium, the strains were grown on Rogosa agar plates and in MRS broth. Growth on solid medium as compared to liquid 
medium induces changes in the expression of cell surface proteins in Staphylococcus aureus [37], some lactobacilli [16, 38] and Streptococcus bovis strains [30]. That is why the similar result with three of four Lactobacillus strains tested is not surprising.

In our previous study [19], three selected inhibitors significantly reduced $\mathrm{Cn}-\mathrm{I}$ binding by Lactobacillus plantarum L 5 strain. However, a possible positive effect of a substance on bacterial binding was not tested previously. The PAA results presented previously on the International symposium on anaerobic microbiology in Prague in November 2000 [39] show that heparin was bound by all our lactobacilli tested.

\section{ACKNOWLEDGEMENTS}

This study was supported by VEGA Grant
2/2043/22.

\section{REFERENCES}

[1] Wadström T, Ljungh A. Glycosaminoglycan-binding microbial proteins in tissue adhesion and invasion: key events in microbial pathogenicity. J Med Microbiol 1999; 48: 223-233. http://dx.doi.org/10.1099/00222615-48-3-223

[2] Ljungh A, Wadström T. Binding of extracellular matrix proteins by microbes. Methods Enzymol 1995; 253: 501-514. http://dx.doi.org/10.1016/S0076-6879(95)53041-X

[3] Salminen S, Isolauri E, Salminen E. Clinical uses of probiotics for stabilizing the gut mucosal barrier: successful strains and future challenges. Antonie Leeuwenhoek 1996; 70: 347-358.

http://dx.doi.org/10.1007/BF00395941

[4] Reid G. The scientific basis for probiotic strains of Lactobacillus. Appl Environ Microbiol 1999; 65: 3763-3766.

[5] Nemcová R, Bomba A, Herich R, Gancarčiková S. Colonization capability of orally administered Lactobacillus strains in the gut of gnotobiotic piglets. Dtsch tierärztl Wschr 1998; 105: 199-200.

[6] Alvarez-Olmos MI, Oberhelman RA. Probiotic agents and infectious diseases: a modern perspective on a traditional therapy. Clin Infect Dis 2001; 32: 1567-1576.

http://dx.doi.org/10.1086/320518

[7] Kimura K, McCartney AL, McConnell MA, Tannock GW. Analysis of fecal populations of bifidobacteria and lactobacilli and investigation of the immunological responses of their human hosts to the predominant strains. Appl Environ Microbiol 1997; 63: 3394-3398.

[8] Vitini E, Alvarez S, Medina M, Medici M, de Budeguer MV, Perdigon G. Gut mucosal immunostimulation by lactic acid bacteria. Biocell 2000; 24: 223-232.

[9] Fuller R, Gibson GR. Modification of the intestinal microflora using probiotics and prebiotics. Scand J Gastroenterol 1997; 222: 28-31.

[10] Parodi PW. The role of intestinal bacteria in the causation and prevention of cancer: modulation by diet and probiotics. Austral J Dairy Technol 1999; 54: 103-121.

[11] Tannock GW. Microbial interference in the gastrointestinal tract. ASEAN J Clin Sci 1981; 2: 2-34.

[12] Lee YK, Salminen S. The coming of age of probiotics. Trends Food Sci Technol 1995; 6: 241-245.

http://dx.doi.org/10.1016/S0924-2244(00)89085-8
[13] Brassart D, Schiffrin EJ. Probiotics for improved gut health. Trends Food Sci Technol 1997; 8: 321-326.

http://dx.doi.org/10.1016/S0924-2244(97)01071-6

[14] Kapczynski, DR, Meinersmann RJ, Lee MD. Adherence of Lactobacillus to intestinal 407 cells in culture correlates with fibronectin binding. Curr Microbiol 2000; 41: 136-141. http://dx.doi.org/10.1007/s002840010107

[15] Westerlund B, Korhonen TK. Bacterial proteins binding to the mammalian extracellular matrix. Mol Microbiol 1993; 9(4): 687-94.

[16] Aleljung P, Paulsson M, Emödy L, Andersson M, Naidu AS, Wadström T. Collagen binding by lactobacilli. Curr Microbiol 1991; 23: 33-38. http://dx.doi.org/10.1007/BF02092306

[17] Aleljung $P$, Shen W, Rozalska B, Hellmann U, Ljungh A, Wadström T. Purification of collagen-binding proteins of Lactobacillus reuteri NCIB 11951. Curr Microbiol 1994; 28 : 231-236. http://dx.doi.org/10.1007/BF01575966

[18] Toba T, Virkola, R, Westerlund B, Bjorkman Y, Sillanpaa J, Vartio T, Kalkkinen N, Korhonen TK. A collagen-binding Slayer protein in Lactobacillus crispatus. Appl Environ Microbiol 1995; 61: 2467-2471.

[19] Štyriak I, Demečková V, Nemcová R. Collagen (Cn-I) binding by gut lactobacilli. Berl Münch Tierärztl Wschr 1999a; 112: 301-304.

[20] Lorca G, Torino MI, deValdez GF, Ljungh A. Lactobacilli express cell surface proteins which mediate binding of immobilised collagen and fibronectin. FEMS Microbiol Lett 2002; 206: 31-37. http://dx.doi.org/10.1111/j.1574-6968.2002.tb10982.x

[21] Vaughan EE, Mollet B, deVos WM. Functionality of probiotics and intestinal lactobacilli: light in the intestinal tract tunnel. Curr Opin Biotechnol 1999; 10: 505-510.

http://dx.doi.org/10.1016/S0958-1669(99)00018-X

[22] Tannock GW. Lactobacillus succession in the piglet digestive tract demonstrated by plasmid profiling. Appl Environ Microbiol 1990; 56: 1310-1316.

[23] Bomba A, Kaštel R, Gancarčiková S, Nemcová R, Herich R, Čižek M. The effect of lactobacilli inoculation on organic acid levels in the mucosal film and small intestine contents in gnotobiotic pigs. Berl Münch Tierärztl Wschr 1996; 109: 428430.

[24] Ocana VS, deRuizHolgado AAP, Nader-Macias ME. Selection of vaginal $\mathrm{H}_{2} \mathrm{O}_{2}$-generating Lactobacillus species. Curr Microbiol 1999; 38: 279-284. http://dx.doi.org/10.1007/PL00006802

[25] Nemcová R, Lauková A, Gancarčiková, S, Kaštel R. In vitro studies of porcine lactobacilli for possible probiotic use. Berl Münch Tierärztl Wschr 1997; 110: 413-417.

[26] Carvalho MGS, Teixeira LM. Hemagglutination properties of Enterococcus. Curr Microbiol 1995; 30: 265-268. http://dx.doi.org/10.1007/BF00295499

[27] Mukai T, Kaneko S, Ohori H. Haemagglutination and glycolipid-binding activities of Lactobacillus reuteri. Lett Appl Microbiol 1998; 27: 130-134. http://dx.doi.org/10.1046/j.1472-765X.1998.00418.x

[28] Adlerberth I, Ahrne S, Johansson ML, Molin G, Hanson L, Wold A.E. A mannose-specific adherence mechanism in Lactobacillus plantarum conferring binding to the human colonic cell line HT-29. Appl Environ Microbiol 1996; 62: 2244-2251.

[29] Naidu AS, Paulsson M, Wadström T. Particle agglutination assays for rapid detection of fibronectin, fibrinogen, and collagen receptors on Staphylococcus aureus. J Clin Microbiol 1988; 26: 1549-1554.

[30] Štyriak I, Lauková A, Fallgren C, Wadström T. Binding of selected extracellular matrix proteins to enterococci and 
Streptococcus bovis of animal origin. Curr Microbiol 1999b; 39: 327-335

http://dx.doi.org/10.1007/s002849900467

[31] Berg RD. The indigenous gastrointestinal microflora. Trends Microbiol 1996; 4: 430-435.

http://dx.doi.org/10.1016/0966-842X(96)10057-3

[32] Neeser JR, Granato D, Rouvet M, Servin A, Teneberg S, Karlsson KA. Lactobacillus johnsonii La1 shares carbohydrate-binding specificities with several enteropathogenic bacteria. Glycobiology 2000; 10: 11931199.

http://dx.doi.org/10.1093/glycob/10.11.1193

[33] Mack DR, Michail S, Wei S, McDougall L, Hollingsworth MA. Probiotics inhibit enteropathogenic E.coli adherence in vitro by inducing intestinal mucin gene expression. Am J Physiol 1999; 276: G941-950.

[34] Jonsson H, Ström E, Roos S. Addition of mucin to the growth medium triggers mucus-binding activity in different strains of Lactobacillus reuteri in vitro. FEMS Microbiol Lett 2001; 204: 19-22.

http://dx.doi.org/10.1111/j.1574-6968.2001.tb10855.x
[35] Roussel P, Lamblin G, Lhermitte M, Houdret N, Lafitte JJ, Perini JM, Klein A, Scharfman A. The complexity of mucins. Biochimie 1988; 70: 1471-1482. http://dx.doi.org/10.1016/0300-9084(88)90284-2

[36] Lindahl $U$, Lidholt $K$, Spillmann $D$, Kjellén $L$. More to "heparin" than anticoagulation. Thromb Res 1994; 75: 1-32. http://dx.doi.org/10.1016/0049-3848(94)90136-8

[37] Cheung AL, Fishetti VA. Variation in the expression of cell wall proteins of Staphylococcus aureus grown on solid and liquid media. Infect Immun 1988; 56: 1061-1065.

[38] Spencer RJ, Chesson A. The effect of Lactobacillus spp. on the attachment of enterotoxigenic Escherichia coli to isolated porcine enterocytes. J Appl Bacteriol 1994; 77: 215-220. http://dx.doi.org/10.1111/j.1365-2672.1994.tb03066.x

[39] Štyriak I, Žatkovič B, Maršalková S. Binding of extracellular matrix proteins by lactobacilli. Folia Microbiol 2001; 46: 8385.

http://dx.doi.org/10.1007/BF02825894 